\title{
Integration and Local Finnish Governments: Local Turn or State Responsibility?
}

\author{
Pekka Kettunen ${ }^{1}$
}

\begin{abstract}
Local governments have become more important in the integration of immigrants, constituting a local turn in integration policy. However, the empirical evidence is still limited and variation between countries is presumably bigh. The present paper analyses the role played by Finnish local governments in the integration process, with municipal governments being highly autonomous from a general European perspective. The paper delineates the basic features of local integration policy, i.e. who does what, and thereafter it assesses the integration plans of local governments and how they justify the current policy. A closer look at Finnish integration policy, however, suggests that state administration actually bas a strong role and that most resources are being directed to integration courses administered by the labour administration of the state. What remains for the local governments is to foresee that their services are suitable for immigrants, too. There is an asymmetry between local governments, though, as immigrants mostly live in larger cities, and half of them in the capital city area. While local governments are obliged to assess their integration policies, such assessments mostly deal with outputs and the feedback of service users. In sum, only a weak. local turn seems to be emerging in Finland.
\end{abstract}

Keywords: Integration; local government; Finland; local turn

\section{Introduction}

The integration of immigrants has been a growing policy issue in most European countries in recent decades (Saunders, 2015; Ireland, 2004; Crul \& Schneider, 2010), and it remains so to this day. Furthermore, there is growing interest in the role of local governments in integration policy. The OECD (2018), for example, claims that local governments are key actors when it comes to integrating immigrants in the receiving countries. Integration as such has a number of definitions. When it comes to local governments, we could assume that their role in integration is connected to different services, with local politics, in general, determining the strategic and day-to-day principles guiding municipal decision making (Denters \& Rose, 2005).

Integration refers to a process by which newcomers receive information and adjust to their new home country (OECD, 2018). The major elements in such a system are language training, work and access to a variety of welfare services. Beyond such elements, there is the larger question of two-way integration, i.e. that newly arrived migrants feel welcome and do not face discrimination. The EU also maintains that integration is a two-way process (Council of the European Union, 2004). Integration can also be viewed as a subjective phenomenon, requiring survey or interview data that adequately reflects the perceptions of the immigrants themselves.

${ }^{1}$ Pekka Kettunen, Migration Institute of Finland, Turku. Finland. E-mail: pekka.kettunen@utu.fi 
At the same time, a number of methodological issues still remain, which will be discussed more in detail in this article.

An analysis of the role of local governments in integration policy offers a number of perspectives on the immigration process in general. Zapata-Barrero et al. (2017: 243) claim that when analysing the role of local governments in integration policy, the emphasis should be either on the horizontal dimension - the local governance of immigrant policies in terms of policymaking arrangements - or on the vertical dimension - how the local governance of immigrant policies enters into complex relations with policymaking processes at other levels of government. Indeed, local governments are regulated by state authorities, more so in centralised states than in decentralised ones (Kuhlmann \& Wollmann, 2019), and this may be reflected in integration policies as well. However, the tasks of local governments may also differ and include both regulated and voluntary tasks.

The following analysis deals with Finland. Finland is a Nordic welfare state in which local governments have a high level of autonomy (Ladner et al., 2015). Integration policy is, however, a relatively new policy area and it is by no means certain how much autonomy local governments actually have in shaping policy. The purpose of the paper is to explore the role of local governments in integration policy and assess the factors determining such a role.

The article proceeds in the following manner. The second section addresses the role of local government in integration policy in general. The third section deals with local integration in Finland, namely the models and policies for successfully managing it as well as how responsibility for integration services is divided between state authorities and local governments. The fourth section takes a closer look at the way local governments in Finland monitor and evaluate their tasks. The data is based on a recent study on the integration policies of four Finnish cities and their integration programmes (Kettunen, 2020). It responds to a central question: How do local governments assess the results of integration measures? The fifth section summarises the findings and presents the conclusions.

\section{The role of local governments in integration policy}

A relevant and significant development in European research on integration has been the 'local turn' of Migration Studies (Zapata-Barrero et al., 2017; Scholten \& Penninx, 2016; Zincone \& Caponio, 2006). The OECD $(2018,24)$ states that local governments must be part of a multi-level governance framework for migrant integration, one that gives them the tools and adequate means to take action. Recent studies direct attention to the local — mainly city - level, which is a level that has become increasingly prominent and entrepreneurial in the field of migrant integration (Zapata-Barrero et al., 2017). The role of local governments in general depends greatly on the policy field in question. On average, we find highly autonomous local governments in Switzerland and the Nordic countries, while autonomy is lower in Southern and Eastern Europe (Ladner et al., 2015). The most autonomous local governments in Europe can be found in Switzerland, Finland, Denmark and Germany, while Georgia, Ireland and Moldova reside at the other end of the spectrum (Ladner et al., 2015).

From the standpoint of implementation (Hill \& Hupe, 2014), local governments can be seen as one type of actor in a multi-layer governance structure. For the EU member countries, it is a question of forming a national integration policy within the EU framework and consisting of either a more centralised or decentralised institutional structure for integration policy

Border Crossing 
implementation (Kulhmann \& Wollmann, 2019). Local governments, in general, are both service providers (more so in Northern Europe than in Southern Europe) and local political actors based on democratic principles. Hence, local governments can be analysed by emphasising their democratic nature (participation, power, legitimacy) or their efficiency and effectiveness in service production (Denters \& Rose, 2005). Successfully managing increasingly diverse local areas in terms of people's places of origin and cultural and religious backgrounds requires effective coordination between central/federal and subnational administrations, active local communities and local authorities capable of designing successful integration policies and adequately communicating their vision to citizens (OECD, 2018: 24).

In the following paragraphs, the emphasis is on the vertical level, with the aim of delineating the state vis-à-vis local government relationship in Finland. When analysing such a vertical relationship, it is relevant to assess the various types of regulations, whether the tasks are compulsory or voluntary, and the incentives offered to local governments to engage in integration activities. A central question is, what kinds of factors determine and condition the interplay between the state and the local governments?

When we discuss the role of local governments in relation to integration policy, we need to clearly delineate their obligations and practices in the field. In Finland, by law, local governments must devise an integration plan or strategy. The plan should provide a good understanding of the goals and contents of the local integration policy. The Integration Law (2010) states that the plans should describe how local governments know that their services serve immigrants and not just Finns, how they plan to cooperate with a variety of actors and how they deal with refugees.

Furthermore, the law states that local governments should monitor and assess all activities, with particular emphasis placed on sufficiently evaluating the local integration policy. Local governments monitor their activities based on OECD guidelines (2018) as well. There are a number of ways to assess the relative success of various integration measures: immigrant employment numbers, education results or visibility in the media are some alternative means for conducting such assessments. Migrants often face great challenges in becoming integrated into their host region's labour market. They have higher unemployment rates, are more likely to be over-qualified for their jobs and earn lower incomes than native-born persons (Saukkonen, 2020).

Local governments assess their services in a number of ways: schools collect information on the progress of pupils and libraries on the quality of their services. Impact analysis is typically based on register data and does not involve qualitative analysis. Hence, it is possible to discover, for example, that fewer immigrant young people continue to upper secondary education compared to native young people, but not to understand the underlying subjective process informing such decisions. In short, integration is not an easy phenomenon to evaluate.

\section{Finnish integration policy at the local level}

Finland only became a receiving country for immigrants in the late 1980s, having been an emigrant country earlier. The share of foreign-born inhabitants has grown since then, and currently (2019), immigrants comprise approximately 7\% of the total population. Now, the most common countries of origin are Russia (and the former Soviet Union), Estonia, Iraq, Somalia and the former Yugoslavia (Statistics Finland). 
Finland's integration policy has been analysed in earlier studies (see Koikkalainen, 2020; Martikainen et al., 2012). Martikainen et al. (2012: 142) argue that despite good intentions, Finnish immigration policies often seem to be too much guided by various short-term domestic political and economic goals rather than a coherent long-term integration objective.

The first law dealing with integration was enacted in 1999, and already ten years later, in 2010, a new law was passed to address the basic tasks in the policy. Although the 2010 Integration Law speaks more to local governments, on the whole, emphasis is placed on the state administration. The responsibility for integration efforts in Finland is divided between state and local authorities, with the main institutionalised processes at both levels dealing with refugees and newly arrived, unemployed immigrants. When a newly arrived immigrant is granted a residence permit, he or she has to register in a specific municipality. The state administration is responsible for unemployed adult persons. Martikainen et al. (2012: 142) claim that, in practice, more resources are dedicated to labour market integration than to other types of integration activities.

The Integration Law (2010) delineates in detail the process in the above case, including both documentation of the basic skills possessed by the immigrant and a year-long integration course. State authorities deal with labour markets, and according to the law, unemployed adults must contact the local state employment agency, where their skills are then assessed. This is followed by an integration course that lasts for approximately one year and consists of language studies and an introduction to working life (Saukkonen, 2020). In recent years, emphasis has increasingly been placed on working life, flexible language education and more rapid processes of integration, putting many immigrants at a crossroads between making a rapid transition to working life and pursuing further education paths, with the former potentially leading to low-skilled work without the option for promotion. In most cases, the one-year course only gives them an introduction to the local language and working life.

After this one-year period, some immigrants continue to work but most move on to vocational education. The various educational institutes nowadays have different tools available to support immigrant students who have not yet acquired sufficient language skills. This means that most immigrants, who apply for the specific purposes of work or on the basis of family relations, are not offered any particular language courses. It then depends on the employer and the immigrant to identify the possibilities and incentives for learning Finnish or Swedish.

Local authorities have a general responsibility to ensure that their services serve immigrants. In practice, this refers to them having access to services and receiving services, adjusted to fit the needs of each immigrant. When considering the integration of new coming immigrants, schools have a particularly important role to play. All children, even those of asylum seekers, are entitled to free education. All schools are in principle, but to varying degrees, prepared to teach domestic languages to immigrant children. The organising of this education varies depending on the number of students, the competence and availability of teachers, and the resources of the municipality.

In other words, integration policy in Finland does not have a strong local presence despite the strong autonomous role of the municipalities. Integration policy at the local level is a relatively new policy area, one that is mostly being developed in the larger cities. While local governments have autonomy in the matter, they usually tend to prioritise more compulsory 
tasks and put less emphasis on voluntary tasks. Integration can be seen as part of the municipal obligation to address the wellbeing of local inhabitants. Koikkalainen (2020) argues that while the general welfare services and benefits provided by the state should be equal for all residents, immigrants may suffer precisely because the system is complicated and does not necessarily recognise their special needs. Due to the freedom afforded local municipalities in arranging their integration activities, the quality of services is not the same throughout the country, as some municipalities are willing to invest more resources than others.

It remains for local governments to assess whether their services are serving immigrants, too. The Integration Law (2010) stipulates that local governments should devise an integration plan for the council period (four years), a plan that should include the local government's plans for how to develop its services in such a way that that they benefit immigrants as well. In smaller municipalities, this may mean individual case-by-case supervising, while in larger ones, it may mean providing particular information services. Municipalities can also do much to address the educational needs of immigrants. However, immigration touches on broader issues than just having access to jobs, education and social and health services, issues ranging from providing immigrants with the information they need to ensure that they participate in cultural life and activities (Kettunen, 2020). Since most local municipal governments in Finland (c. 309) are rather small in size, and since most immigrants live in larger cities, not every local government feels that it is necessary to accommodate immigrants. For larger local governments, it is a question of providing information in multiple languages, training the personnel and supporting local associations in dealing with immigrants, to name but a few issues.

\section{How do local governments assess their services?}

Local governments also must monitor and evaluate the results of immigrant integration efforts and inform the local council of them. When looking more closely at local integration plans, the focus of particular local municipalities and the extent to which they assess how well immigrants are being integrated becomes evident. The OECD (2018: 38) claims that among the dimensions that need to be considered, migrants' local living conditions, as well as their outcomes in the labour market or in education, are crucial. For instance, precise information on migrants' employment rates, their income and the degree to which their qualifications are recognised and adequately made use of in their host communities can be helpful in eliciting systematic integration challenges, especially if they are juxtaposed with the outcomes of local non-migrant residents.

The following data consists of the integration programmes in the four cities in focus here. To compare the data, we selected four areas of activities for detailed analysis. Table 1 provides the findings, i.e. what the four programmes define as indicators or information that helps them assess the results.

Table 1 shows that local governments assess the different services mostly via numerical data. In terms of education, the four cities are identical and focus on the important stage of whether or not pupils choose to pursue a secondary education. Secondary education, either high school or vocational school, constitutes an important step towards entering working life or pursuing additional education. In terms of social and health services, the measures vary, but in essence, they deal either with studying how immigrants use services in general or an assessment provided by the service users themselves. The assessment can either focus on a sample of 
service users or be connected to all visits in some way. In terms of housing, three of the cities monitor the share of immigrants in different housing areas. In Helsinki, this is part of the general housing strategy of the city, i.e. to provide a mix of different types of housing in different areas and to avoid segregation. In the two other cases, Turku and Tampere, the cities gather information on where different migrant groups live. Finally, social engagement forms a broader area of focus, and hence, the assessments vary in that respect, ranging from tracking association memberships to museum visits. In several cases, the examined local governments also plan to use qualitative information in the future: client surveys regarding social and health services (Helsinki), the use of housing counselling services (Oulu) and quality of life measures (Turku). The last mentioned case is, in practice, based on indicators and not directly connected with the use of services.

Table 1. Evaluation data from the four examined cities

\begin{tabular}{|c|c|c|c|c|}
\hline & Schools & $\begin{array}{l}\text { Social and health } \\
\text { services }\end{array}$ & Housing & $\begin{array}{l}\text { Social } \\
\text { engagement }\end{array}$ \\
\hline Helsinki & $\begin{array}{l}\text { Pupils } \\
\text { (immigrant) } \\
\text { approved to } \\
\text { continue with } \\
\text { secondary } \\
\text { education }\end{array}$ & Client survey & $\begin{array}{l}\text { Follow-up on } \\
\text { segregation } \\
\text { (level, between } \\
\text { housing areas) }\end{array}$ & $\begin{array}{l}\text { Share of new } \\
\text { members in } \\
\text { associations } \\
\text { (immigrant) }\end{array}$ \\
\hline Oulu & $\begin{array}{l}\text { Pupils } \\
\text { (immigrant) } \\
\text { approved to } \\
\text { continue with } \\
\text { secondary } \\
\text { education }\end{array}$ & $\begin{array}{l}\text { Follow-up of } \\
\text { service users } \\
\text { (immigrants) }\end{array}$ & $\begin{array}{l}\text { Use of advice } \\
\text { and information } \\
\text { services }\end{array}$ & $\begin{array}{l}\text { New members } \\
\text { (immigrants) in } \\
\text { associations }\end{array}$ \\
\hline Tampere & $\begin{array}{l}\text { Pupils } \\
\text { (immigrant) } \\
\text { approved to } \\
\text { continue with } \\
\text { secondary } \\
\text { education }\end{array}$ & $\begin{array}{l}\text { Share of } \\
\text { immigrant clients } \\
\text { in services }\end{array}$ & $\begin{array}{l}\text { Share of } \\
\text { different migrant } \\
\text { groups in } \\
\text { housing areas }\end{array}$ & $\begin{array}{l}\text { Visits to cultural } \\
\text { institutions } \\
\text { (immigrant) }\end{array}$ \\
\hline Turku & $\begin{array}{l}\text { Pupils } \\
\text { (immigrant) } \\
\text { approved to } \\
\text { continue with } \\
\text { secondary } \\
\text { education }\end{array}$ & $\begin{array}{l}\text { Subjective } \\
\text { perceptions of } \\
\text { quality of life }\end{array}$ & $\begin{array}{l}\text { Share of } \\
\text { immigrants in } \\
\text { different housing } \\
\text { areas }\end{array}$ & $\begin{array}{l}\text { Rate of } \\
\text { participation in } \\
\text { associations } \\
\text { (immigrant) }\end{array}$ \\
\hline
\end{tabular}

Table 1 suggests that the four cities are relatively similar and that their emphasis is on outputs rather than outcomes. The manner in which local governments collect data more closely resembles monitoring than evaluation. The examined cities count in numerous ways the number of visitors, pupils, participants and inhabitants in housing areas. Sometimes the numbers mean more, say in the case of how many immigrant youngsters pursue secondary education and/or higher education. Sometimes the figures can be readily discussed, such as when counting the number of non-domestic language speakers in certain housing areas, but such statistics do not otherwise contain much information. 
While quantitative information is necessary, conclusions cannot be drawn based solely on such information concerning the relative success of integration. What the local governments track, understandably, are the kinds of services they provide and the extent to which the services also work well for immigrant clients. Additional resources are needed in some cases, for instance, with respect to education (language teachers) or information (employees mastering several languages), but in other cases (culture, housing) there is no need to arrange separate services for immigrants. Numbers work especially well in a comparative approach. For example, Dunlevy et al. (2020: 35) found that approximately 60-65 per cent of refugee children who arrived before the age of seven had completed upper secondary education by the age of 25 in Denmark, compared to 58\% in Finland and 66\% in Norway, whereas the vast majority did so in Sweden. However, it would be important to know why the numbers differ, i.e. what lies behind the differences.

An obvious reason for the emphasis on outputs is that they are quantitative and measurable factors (Clarke, 1999). However, this is not identical to saying that such immigrants have been integrated. This would demand deeper level information on the prevalence of discrimination, hindrances and/or subjective perspectives. On the other hand, this type of analysis would require more resources and data, which individual local governments do not necessarily possess. In Finland, the city of Helsinki constitutes an exception, and its research unit has provided several reports on the other aspects of integration.

When it comes to other services, no statistics exist that speak to whether immigrants receive the same level of services as native citizens. Neither do statistics measure racist attacks, hateful media content or visible signs of prejudice in public, such as in cultural life and so forth. Ireland (2004: 15) states that integration can be seen as a series of processes by which immigrants and those of immigrant origin engage with and become part of their host society. Saunders (2015) has presented data on the perceptions and values of immigrants in a number of countries. Impacts are not an easy target to measure: we could ask if immigrant children (both first and second generation) are well integrated (Chen, 2005). We should not assume, though, that integration can be assessed through public service systems; it must be seen as a holistic process containing several overlapping processes, not necessarily as proceeding in a linear fashion (Phillimore \& Goodson, 2019). Comparative analysis may help in understanding the importance of the local or national institutions affecting the integration process. Crul and Schneider (2010: 1259) have noted that progress in education can depend on a child's starting age in school, the age during the first track selection, the upward permeability within secondary education and the existence of a long or indirect route to higher education through the vocational stream.

\section{Discussion}

A question was posed at the beginning of the paper: What is the role of local governments in the integration of immigrants? The preceding analysis suggests that Finnish municipalities do not play a major role in the integration process, as the main resources are administered by the state. The local integration system in Finland is rather fragmented. The division of labour between the state and local governments is not, however, fixed in Finland. In March 2021, a number of local governments will assume responsibility for the employment of a number of groups, including immigrants. This is a pilot programme, the aim of which is to see if local governments succeed better in reducing unemployment. Paradoxically, despite the labour 
shortage that is predicted for the future, many of the immigrants already in the country find it difficult to gain access to the labour market. Furthermore, the jobs available to them tend to be unskilled and insecure (Martikainen et al., 2021: 142).

Integration proper is the responsibility of the state (albeit it is also partially the role of larger cities), while local governments mainly manage the integration process through services. This is by no means a minor challenge since in larger cities, the constant flux of migration workers, EU citizens and refugees requires modified services. Schools play a central role in the process. If schools have enough resources (both in terms of money and skills), they can then assist immigrant children in learning Finnish or Swedish while at the same time maintaining their mother tongue. The success of this policy is measured against the goal of having no background-related differences between pupils. So far, the goal has not been realised. The same applies to culture policy, which can greatly influence the general value climate of a municipality and provide multi-cultural diversity. This goal is understandably more difficult to measure.

While local governments do assess their services, the emphasis is on monitoring rather than evaluation (Vedung, 2009). It is much easier to collect output-related information than outcomes, especially in such policy sectors as school or employment or even in measuring political participation (Pollitt, 2003). When it comes to assessing overall integration, however, such as the feeling of being a part of society, then it becomes more difficult to collect representative data. In general, very few municipalities compile and publish statistical data used for monitoring integration. Moreover, household surveys often have very small migrant samples, which cannot be considered representative (OECD, 2018: 142).

A particular problem when evaluating integration results is the heterogeneity of immigrants. When we say that a certain housing area is segregated, are we then referring to all immigrants or just to certain immigrants? Furthermore, in some policy fields, the critical factor is income and not ethnicity when assessing, say, a particular housing market. Benton and Ahad (2019: 3) argue that newcomers are heterogeneous in their characteristics and needs, while host societies are hardly harmonious monoliths either, meaning there is often little agreement over how and how much each group should adjust. A short-time visit can turn into a longer visit. Finland, like many other European countries, has in recent decades experienced a demographic downturn, with Finnish mothers having fewer children. Immigration can thus be seen as a measure to change such a development. Immigrants may include short-time visitors benefiting from the free movement of labour within the European Union or temporary immigrants, such as seasonal agricultural workers. Still, it typically takes time for all newly arrived persons to become settled in the new country. Ireland (2004: 16) argues that a neighbourhood with high concentrations of persons of immigrant origin could serve to lock such individuals within an encapsulated society, or it could represent a temporary but indispensable incubation stage in a gradual process of integration.

So, ultimately what is the role of local governments? When it comes to integration courses for newly arrived immigrants, the state administration takes the lead. This has been noted in earlier studies, which label the Finnish integration policy a labour-related policy (Koikkalainen, 2020; anon., 2020). Zapato-Barrero et al. (2017) raise the question of why and how cities and regions respond differently to similar challenges. Local governments are not identical. Their size plays a role, as does their immigrant population. Almost half of all immigrants live in the vicinity of the Helsinki Metropolitan Area. More immigrants live in larger cities than in rural areas, where

Border Crossing 
the number of immigrants is small (Martikainen et al., 2012). This means that the state regulation must be asymmetrical by nature. In practice, only the larger cities in Finland have invested in multi-language information services and culture centres promoting openness. On the other hand, the smaller ones deal with immigrants on a case-by-case basis.

However, local governments may do more. Usually, local governments do only what is compulsory. In addition, immigration is, in the final analysis, a policy issue only for the larger cities. If they so choose, they can establish information one-post services, cooperate with the third sector and institute a more active housing policy. This is what even the OECD (2018) recommends and what the main cities in Europe are already doing. Finland may follow suit.

Local governments can try to achieve results by the best means available. Benton and Ahad (2019: 19) argue that integration policy-makers have numerous new tools at their disposal to address these challenges, many of which have been tried and tested in other policy areas. This may be one way to improve services and the integration process. Local governments can also find ways to benefit from research results, say by cooperating with academic institutions, or larger cities can invest in hiring employees to assess the success of the current integration policy. Furthermore, immigrants themselves are only rarely invited to assess the quality of services or the benefits of such services. In many other local government services, and in private business, service design is a popular term: Why not extend it to integration services as well? At the end of the day, it is still a matter of subjective judgement as to whether a person feels integrated or not.

\section{References}

Benton, M. \& Ahad, A. (2019). Breaking New Ground, Ten Ideas to Revamp Integration Policy in Europe. Brussels: Migration Policy Institute.

Chen, H.-T. (2005). Practical Program Evaluation. Assessing and Improving Planning, Implementation and Effectiveness. Thousand Oaks: Sage.

Clarke, A. (1999). Evaluation Research. An Introduction to Principles, Methods ad Practice. London: Sage.

Council of the European Union. (2004). Immigrant Integration Policy in the European Union. Brussels, 19 November. 14615/04 (Presse 321),

Crul, M. and Schneider, J. (2010). "Comparative integration theory: participation and belonging in new diverse European cities”. Ethnic and Racial Studies 33: 1249-1268.

Denters, B. and Rose, L.E. (2005). Comparing local governance. Trends and developments. Houndmills, Basingstoke: Palgrave Macmillan.

Dunlevy, A., Jamili, C., de Montgomery, J., Lorentzen, T., Malin, M. \& Hjern, A. (2020). Equity in Education? A comparative analysis of educational outcomes among refugee children in the Nordic countries. CAGE project report 1.

Hill, M. \& Hupe, P. (2014). Implementing Public Policy. Third edition. London: Sage.

Ireland, P. (2004). Becoming Europe. Immigration, Integration, and the Welfare State. Pittsburgh, PA: Pittsburgh University Press.

Kettunen, P. (2020) Kuntien maahanmunttopalvelut: Haasteita ja byviä käytäntöjä. Helsinki: Kunnallisalan kehittämissäätiö.

Koikkalainen, S. (2020). "Finland's Immigration Policy: State Objectives, Local Solutions". In: J. Franzke and J. Ruano de la Fuente (eds.) Local Integration of Migrants Policy: European Experiences and Challenges. Palgrave Macmillan, 53-71.

Kuhlmann, S. and Wollmann, H. (2019). Introduction to Comparative Public Administration. Administrative Systems and Reforms in Europe. Cheltenham: Edward Elgar. 
76 Integration and Local Finnish Governments: Local Turn or State Responsibility?

Ladner, A., Keuffer, N. and Baldersheim, H. (2015). Local Autonomy Index for European countries (1990-2014). Release 1.0. Brussels: European Commission.

Martikainen, T., Valtonen, K. and Wahlbeck, O. (2012). “The Social Integration of Immigrants in Finland”. In: J. Frideres and J. Biles (eds.) International Perspectives: Integration and Inclusion. McGill-Queen's University Press, 127-146.

OECD. (2018). Working Together for Local Integration of Migrants and Refugees. Paris: OECD Publishing,

Phillimore, J. and Goodson, L. (2019). "Making a Place in the Global City: The Relevance of Indicators of Integration”. Journal of Refugee Studies 21: 305-325.

Pollitt, C. (2003). The Essential Public Manager. Maidenhead: Open University Press.

Saukkonen, P. (2020). Suomi omaksi kodiksi. Kotouttamispolitiikeka ja sen kehittämismabdollisundet. Helsinki: Gaudeamus.

Saunders, D. (2015). The Myth of the Muslim Tide: Do Immigrants Threaten the West? New York and Toronto: Random House.

Scholten, P. and Penninx, R. (2016). "The Multilevel Governance of Migration and Integration”. In: B. Garcés-Mascareñas and R. Penninx (eds.) Integration Processes and Policies in Europe. Springer, pp. 91-108.

Vedung, E. (2009). Utvärdering i politik och förvaltning. Lund: Studentlitteratur.

Zapata-Barrero, R., Caponio, T. and Scholten, P. (2017). "Theorising the 'local turn' in a multi-level governance framework of analysis: a case study in immigrant policies". International Review of Administrative Sciences 83(2): 241-246. doi:10.1177/0020852316688426

Zincone, G. and Caponio, T. (2006). "The Multilevel Governance of Migration”. In: R. Penninx, M. Berger and K. Kraal (eds.) The Dynamics of International Migration and Settlement in Europe. A State of the Art. Amsterdam University Press, 269-304. 